\title{
EFEKTIVITAS PENERAPAN RESTORATIVE JUSTICE DALAM MENYELESAIKAN KASUS TINDAK PIDANA DI WILAYAH HUKUM POLRES PUNCAK JAYA
}

\section{Dedy Syahputra Bintang}

Universitas Tarumanagara (UNTAR) Jakarta, Indonesia

Email: putramagisterhukum@gmail.com

\section{Abstract}

Restorative justice has been used by the Puncak Jaya Resort Police (Polres) in a number of criminal cases that happened within the Puncak Jaya Police's jurisdiction. This is because if a case is not settled by customary law, the Puncak Jaya community is often dissatisfied. Positive legislation is thought to be less sensitive to the needs of the society when it comes to criminal proceedings. The Puncak Jaya Police Department uses a restorative justice approach to mitigate the occurrence of new issues that could arise as a result of aggrieved parties' frustration. This study is a normative legal study that was performed using qualitative approaches and secondary data sources. The data is gathered from reliable sources based on literature reviews. In an inductive method, where research is conducted from general to more specific topics, conclusions are drawn from the research. The restorative justice strategy can be considered a viable option for resolving criminal cases in Puncak Jaya. This is because, in some circumstances, the restorative justice approach is a form of settlement that can satisfy the wishes of the parties concerned. In order for the matter to be settled according to the desires of the parties concerned. The Puncak Jaya community's customary law includes the payment of customary fines as one form of punishment. Customary fines are intended to compensate the victim for the harm caused by the perpetrator's criminal act. As a result, any customary fines that all parties have settled upon must be charged. he customary law payment is made at the police department in front of prosecutors and other interested parties.

Keywords: customary law; restorative justice; Puncak Jaya
Abstrak
Restorative justice telah digunakan oleh Kepolisian Resor (Polres) Puncak Jaya dalam sejumlah kasus kriminal yang terjadi di wilayah hukum Polres Puncak Jaya. Hal ini dikarenakan jika sebuah kasus tidak diselesaikan oleh hukum adat, masyarakat Puncak Jaya seringkali tidak puas. Undang-undang positif dianggap kurang sensitif terhadap kebutuhan masyarakat dalam hal proses pidana. Polres Puncak Jaya menggunakan pendekatan restorative justice untuk memitigasi terjadinya isu-isu baru yang dapat muncul sebagai akibat dari frustrasi pihak-pihak yang tergugah. Penelitian ini merupakan kajian hukum normatif yang dilakukan dengan menggunakan pendekatan kualitatif dan sumber data sekunder. Data dikumpulkan dari sumber terpercaya berdasarkan tinjauan literatur. Dalam metode induktif, di mana penelitian dilakukan dari umum ke topik yang lebih spesifik,

\begin{tabular}{ll}
\hline How to cite: & Bintang, Dedy Syahputra (2021) Efektivitas Penerapan Restorative Justice Dalam Menyelesaikan \\
& Kasus Tindak Pidana Di Wilayah Hukum Polres Puncak Jaya, (3)6 https://doi.org/10.36418/syntax- \\
& idea.v3i6.1226 \\
E-ISSN: & 2684-883X \\
Published by: & Ridwan Institute
\end{tabular}


kesimpulan diambil dari penelitian. Strategi restorative justice dapat dianggap sebagai pilihan yang layak untuk menyelesaikan kasus pidana di Puncak Jaya. Hal ini dikarenakan, dalam beberapa keadaan, pendekatan restorative justice merupakan bentuk penyelesaian yang dapat memuaskan keinginan para pihak yang bersangkutan. Agar persoalan tersebut dapat diselesaikan sesuai dengan keinginan pihak-pihak yang bersangkutan. Hukum adat masyarakat Puncak Jaya meliputi pembayaran denda adat sebagai salah satu bentuk hukuman. Denda adat dimaksudkan untuk memberikan kompensasi kepada korban atas kerugian yang ditimbulkan akibat tindak pidana pelaku. Akibatnya, setiap denda adat yang telah diselesaikan semua pihak harus dibebankan. pembayaran hukum adat dilakukan di kepolisian di depan kejaksaan dan pihak lain yang berkepentingan.

Kata Kunci: hukum adat; keadilan restoratif; Puncak Jaya

\section{Pendahuluan}

Undang-undang Republik Indonesia menggunakan istilah tindak pidana untuk menggambarkan kegiatan atau perbuatan yang melanggar hukum. Istilah tindak pidana berasal dari suatu istilah dalam hukum pidana Belanda, yaitu strafbaarfeit. Walaupun istilah tersebut terdapat dalam Wetboek van Strafrecht (WvS) Belanda maupun berdasarkan asas konkordasi, istilah tersebut juga berlaku pada WvS Hindia Belanda (Kitab Undang-Undang Hukum Pidana) (Purba, 2016).

Hukum pidana, yaitu pelanggaran norma-norma dalam tiga bidang hukum lain, yaitu Hukum Perdata, Hukum Ketatanegaraan, dan Hukum Tata Usaha Pemerintah, yang oleh pembentuk Undang-Undang ditanggapi dengan suatu hukum pidana. Maka sifat-sifat yang ada dalam suatu tindak pidana adalah sifat melanggar hukum, karena tidak ada suatu tindak pidana tanpa melanggar hukum (Jaelani, 2020).

Pada prinsipnya, hukum pidana tidak mengenal adanya mekanisme penyelesaian tindak pidana di luar dari pada pengadilan. Berbeda dengan hukum perdata yang mengenal adanya penyelesaian sengketa di luar pengadilan (non litigasi) yang disebut juga dengan istilah Alternatif Penyelesaian Sengketa (APS). Menurut Undang-Undang Nomor 30 Tahun 1999 tentang Arbitrase, dijelaskan bahwa Alternatif Penyelesaian Sengketa adalah lembaga penyelesaian sengketa atau beda pendapat melalui prosedur yang disepakati para pihak, yakni penyelesaian di luar pengadilan dengan cara konsultasi negosiasi, mediasi, konsiliasi, atau penilaian ahli. APS hanya bisa diberlakukan untuk kasus perdata, bukan untuk pidana (Ariani, 2012)

Saat ini satu-satunya Undang-Undang di Indonesia yang mengatur terkait tindak pidana yang penyelesaiannya dapat dilakukan di luar pengadilan adalah UndangUndang Nomor 11 Tahun 2012 tentang Sistem Peradilan Pidana Anak (Indonesia, 2012), dimana bentuk penyelesaiannya dikenal dengan istilah diversi, yaitu pengalihan penyelesaian perkara anak dari peradilan pidana berdasarkan keadilan restoratif.

Penyelesaian perkara tindak pidana dengan melibatkan pelaku, korban, keluarga pelaku/korban dan pihak lain yang terkait untuk bersama-sama mencari penyelesaian yang adil dengan menekankan pemulihan kembali pada keadaan semula dan bukan pembalasan (Wahyudi, 2015). 
Walau diatur dalam Undang-Undang Pidana Anak untuk lebih dianjurkan diaplikasikan dalam kasus pemidanaan pada anak, namun restorative justice juga dilakukan dalam kasus pemidanaan umum. Hal tersebut juga disarankan untuk dilakukan sesuai dengan Surat Edaran Kapolri No: SE/8/VII/2018 Tanggal 27 Juli 2018. Surat edaran tersebut dikeluarkan dengan pertimbangan bahwa restorative justice dapat menjawab perkembangan kebutuhan hukum masyarakat serta memenuhi rasa keadilan semua pihak.

Kepolisian Resor (Polres) Puncak Jaya sudah menerapkan restorative justice dalam menangani beberapa kasus pidana yang terjadi di wilayah hukum Polres Puncak Jaya. Hal tersebut dikarenakan masyarakat Puncak Jaya sering merasa tidak puas jika suatu kasus tidak diselesaikan dengan hukum adat. Penyelesaian kasus tindak pidana dengan hukum positif dirasa kurang mengakomodir keinginan masyarakat.

Maka dari itu, menyelesaikan perkara pidana dengan pendekatan restorative justice dianggap lebih cocok untuk diselesaikan di wilayah hukum Puncak Jaya. Peradilan dengan menggunakan pendekatan restorative justice yang dilakukan di wilayah hukum Polres Puncak Jaya dilakukan demi meminimalisir timbulnya masalah baru yang bisa saja terjadi akibat ketidakpuasan dari pihak-pihak yang merasa dirugikan.

\section{Metode Penelitian}

Penelitian ini merupakan kajian hukum normatif yang dilakukan dengan menggunakan pendekatan kualitatif dan sumber data sekunder. Data dikumpulkan dari sumber terpercaya berdasarkan tinjauan literatur. Dalam metode induktif, di mana penelitian dilakukan dari umum ke topik yang lebih spesifik, kesimpulan diambil dari penelitian. Strategi restorative justice dapat dianggap sebagai pilihan yang layak untuk menyelesaikan kasus pidana di Puncak Jaya. Hal ini dikarenakan, dalam beberapa keadaan, pendekatan restorative justice merupakan bentuk penyelesaian yang dapat memuaskan keinginan para pihak yang bersangkutan. Agar persoalan tersebut dapat diselesaikan sesuai dengan keinginan pihak-pihak yang bersangkutan.

\section{Hasil dan Pembahasan}

\section{A. Keberhasilan Penerapan Restorative Justice dalam Menyelesaikan Kasus Pidana di Papua}

Penerapan pendekatan restorative justice sudah lama dilakukan di Polres Puncak Jaya. Bahkan sejak pertama kali Polres Puncak Jaya terbentuk di pertengahan 2008, pendekatan restorative justice adalah metode yang digunakan untuk menyelesaikan kasus tindak pidana. Hal tersebut dikarenakan masyarakat Puncak Jaya yang cenderung lebih memilih untuk menggunakan hukum adat dalam menyelesaikan kasus tindak pidana. Oleh karena itu, maka pendekatan retosrative justice dalam menyelesaikan kasus tindak pidana dianggap lebih efektif (Umam, 2016).

Efektivitas merupakan kemampuan dalam melaksanakan tugas, fungsi (operasi kegiatan program atau misi) dari suatu organisasi atau sejenisnya yang tidak ada 
tekanan atau ketegangan diantara pelaksanaannya (Maharani, Yuniningsih, \& Djumiarti, 2016). Penerapan pendekatan restorative justice dilaksanakan oleh Polri sebagai aparat hukum yang bertugas untuk melaksanakan penegakan hukum.

Penerapan restorative justice dilaksanakan oleh Polres Puncak Jaya sebagai upaya dalam penegakan hukum di tengah-tengah masyarakat. Dimana penegakan hukum dilaksanakan agar terciptanya kondisi yang aman dan damai, serta mendamaikan pihak-pihak yang terlibat perkara. Efektivitas hukum menurut Romli Atmasasmita yaitu faktor-faktor yang menghambat efektivitas penegakan hukum, tidak hanya terletak pada sikap mental aparat penegak hukum (hakim, jaksa, polisi dna penasihat hukum) akan tetapi juga terletak pada faktor sosialisasi hukum yang sering diabaikan (Tarigan, 2017).

Untuk melihat atau mengukur keberhasilan dari efektif tidaknya suatu hukum, dapat dilakukan dengan melakukan pengukuran pada 5 (lima) faktor yaitu (Pohan, 2019) :

a. Faktor hukumnya itu sendiri (undang-undang)

b. Faktor penegak hukum, yakni pihak-pihak yang membentuk maupun menerapkan hukum

c. Faktor sarana dan fasilitas hukum yang mendukung penegakan hukum

d. Faktor masyarakat, yakni lingkungan dimana hukum tersebut berlaku atau diterapkan

e. Faktor kebudayaan, yakni sebagai hasil karya cipta dan rasa yang didasarkan pada karsa.

Jika dilakukan analisa untuk melihat ukuran efektivitas penerapan restorative justice di Polres Puncak Jaya berdasarkan pada faktor-faktor yang disebutkan oleh Soerjono Soekanto, maka bisa digambarka $\mathrm{n}$ pada tabel dibawah ini:

Tabel 1

\begin{tabular}{llll}
\hline No & \multicolumn{1}{c}{ Faktor } & \multicolumn{2}{c}{ Penerapan Restorative Justice di Polres Puncak Jaya } \\
\hline 1 & Hukumnya & $\begin{array}{l}\text { Landasan restorative justice, Surat Edaran Kapolri } \\
\text { No.8/VII/2018 dan Keputusan Direktur Jenderal Badan } \\
\end{array}$ & $\begin{array}{l}\text { Peradilan Umum Mahkamah Agung Republik Indonesia } \\
\text { Nomor 1691/DJU/SK/PS.00/12/2020 }\end{array}$ \\
\hline 2 & Penegak Hukum & Kepolisian Resor Puncak Jaya \\
\hline 3 & $\begin{array}{l}\text { Sarana dan fasilitas } \\
\text { yang mendukung }\end{array}$ & Kantor Kepolisian Resor Puncak Jaya \\
\hline 4 & Masyarakat & $\begin{array}{l}\text { Masyarakat Puncak Jaya sebagai masyarkat yang } \\
\text { memegang teguh nilai-nilai serta kebiasaan luhur. hukum }\end{array}$ \\
& & $\begin{array}{l}\text { adat merupakan hukum yang berasal dari masyarkaat } \\
\text { Puncak Jaya }\end{array}$ \\
\hline 5 & Kebudayaan & $\begin{array}{l}\text { Sebagai masyarakat adat yang memegang teguh nilai-nilai } \\
\text { kebudayaan yang ada, masayrkat Puncak Jaya masih } \\
\text { mengakui dan menerapkan hukum adat dalam } \\
\end{array}$ \\
& $\begin{array}{l}\text { menyelesaikan kasus tindak pidana yang terjadi. dimana } \\
\text { hukum adat merupakan hukum yang berasal dari } \\
\text { masyarakat Puncak Jaya dan tetap hidup ditenagh-tengah }\end{array}$ \\
\hline
\end{tabular}


Efektivitas Penerapan Restorative Justice dalam Menyelesaikan Kasus Tindak Pidana

\begin{tabular}{lll}
\hline No & Faktor & \multicolumn{2}{c}{ Penerapan Restorative Justice di Polres Puncak Jaya } \\
\hline & $\begin{array}{l}\text { masayarakat. hukum adat sudah menjadi bagian dari } \\
\text { kebudayaan masyarakat Puncak Jaya. }\end{array}$ \\
\hline
\end{tabular}

Menambahkan pada faktor-faktor pengukur efektivitas diatas, Soerjono Soekanto memprediksi patokan efektivitas elemen-elemen tertentu dari prasarana. Dimana prasarana yang dimaksud harus secara jelas menjadi bagian yang memberikan kontribusi untuk kelancaran tugas-tugas aparat di lokasi kerjanya (Rahman, 2017). Walau tidak sebanding jika dibandingkan dengan Polres di Kabupaten lain yang bukan berada di wilayah gunung, Kepolisian Resor Puncak Jaya memiliki sarana dan prasarana yang mumpuni untuk menerapkan restorative justice dalam menyelesaikan kasus tindak pidana di Puncak Jaya.

Melihat tabiat dari masyarakat Puncak Jaya yang suka berperang, maka pendekatan restorative justice dalam menyelesaikan kasus tindak pidana di Puncak Jaya bisa dikatakan efektif. Hal tersebut bisa dilihat dari tidak terjadinya perang antar suku ketika sudah dilaksanakan pendekatan restorative justice dalam kasus tindak pidana yang terjadi. kemudian hal lain yang bisa dijadikan ukuran adalah, banyaknya kasus tindak pidana yang diminta oleh masyarkaat untuk diselesaikan dengan pendekatan restorative justice. Hal tersebut dapat dilihat pada data reskrim Polres Puncak Jaya, seperti yang tertera pada diagram dibawah ini.

\section{Diagram 2}

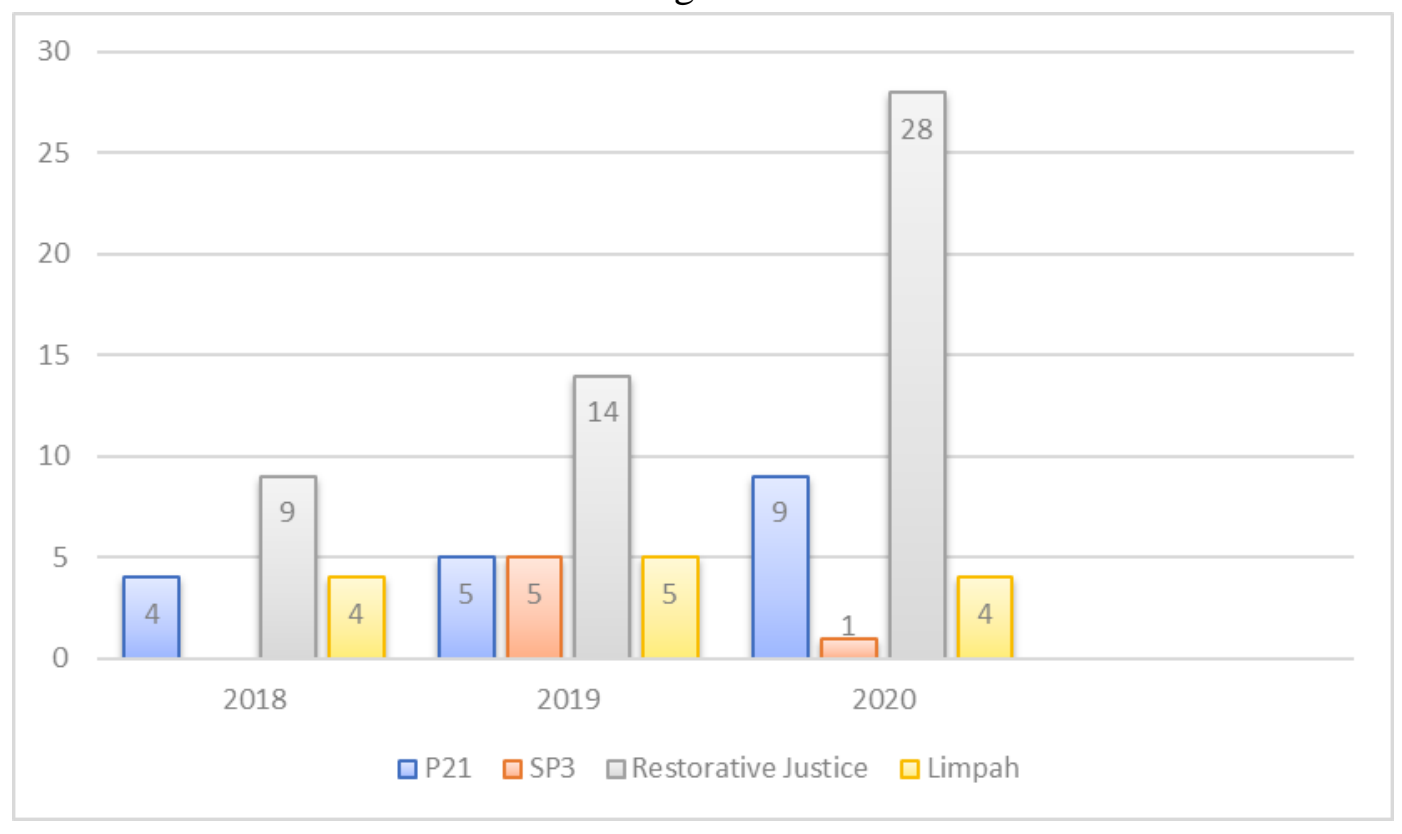

Laporan kasus tindak pidana yang terjadi di Polres Puncak Jaya periode 2018-2020. Diolah oleh peneliti 


\section{B. Hal-hal yang Menjadi Pertimbangan Penyidik dalam Menerapkan Restorative Justice dalam Menyelesaikan suatu Kasus Pidana di Papua}

Pihak-pihak yang terlibat dalam suatu kasus tindak pidana, memiliki hak penuh untuk memilih akan menyelesaikan kasus tindak pidana yang terjadi dengan pendekatan restorative justice atau tidak. Penyidik atau pihak kepolisian tidak boleh melakukan intervensi terhadap hal tersebut. Walau tidak boleh untuk melakukan intervensi, namun pihak penyidik berhak untuk mempertimbangkan apakah kasus tersebut bisa diselesaikan dengan pendekatan restorative justice atau tidak. Karena berdasarkan pada Pasal 7 ayat (1) huruf J Undang-Undang Nomor 08 tahun 1981 tentang Hukum Acara Pidana, disebutkan bahwa penyidik karena kewajibannya mempunyai wewenang mengadakan tindakan lain menurut hukum yang bertanggung jawab (Apriyanto, 2016).

Kemudian pada Pasal 16 Ayat (1) huruf L dan Pasal 18 Undang-Undang Nomor 2002 tentang Kepolisian Negara Republik Inodnesia dan Pasal 6 Ayat (1) angka 4 Undang-Undang Nomor 08 tahun 1981 tentang Hukum Acara Pidana, bahwa tindakan lain sebagaimana dimaksud dalam Pasal 16 ayat (1) huruf L adalah tindakan penyelidikan dan penyidikan yang dilaksanakan jika memehuni syarat (Pandelaki, 2018) berikut ini:

1) Tidak bertentangan dengan suatu aturan hukum;

2) Selaras dengan hukum yang mengharuskan tindakan tersebut dilakukan;

3) Pertimbangan yang layak berdasarkan keadaan yang memaksa;

4) Harus masuk akal, patut, dan termasuk dalam lingkungan jabatannya; dan

5) Menghormati Hak Asasi Manusia (HAM).

Selain hal-hal yang disebutkan dalam Undang-Undang tersebut, terdapat halhal lain yang harus menjadi pertimbangan penyidik dalam memutuskan bahwa suatu kasus dapat diselesaikan dengan restorative justice atau tidak. Adapun hal tersebut adalah salah satu syarat formil pada pedoman penanganan penyelesaian perkara dengan pendekatan restorative justice yang terdapat pada Surat Edaran Kapolri No.8 Tahun 2018, bahwa semua tindak pidana dapat dilakukan restorative justice terhadap kejahatan umum yang tidak menimbulkan korban manusia. Maka penerapan restorative justice tidak dapat dilakukan pada tindak pidana yang menyebabkan hilangnya nyawa manusia.

Maka dalam menyelesaiakn kasus tindak pidana dengan pendekatan restorative justice, hal-hal tersebut harus menjadi pertimbangan penyidik untuk dapat menentukan suatu kasus tindak pidana dapat diselesaikan dengan pendekatan restorative justice atau tidak.

\section{Kondisi dari Pihak-Pihak yang Terlibat dalam Kasus Pidana Ketika Penyelesaian kasus Pidananya Diselesaikan dengan Menerapkan Restorative Justice}

Pendekatan restorative justice bisa dikatakan sebagai metode penyelesaian yang cocok terhadap kasus tindak pidana yang terjadi di Puncak Jaya. Hal tersebut disebabkan karena pendekatan restorative justice merupakan metode penyelesaian 
yang dalam prakteknya mampu mengakomodir keinginan dari pihak-pihak yang terlibat perkara tertentu. Sehingga perkara yang terjadi dapat diselesaikan dengan sesuai dengan kehendak para pihak yang terlibat (Bintang, 2021).

Dengan menyepakati penerapan restorative justice oleh kedua belah pihak yang terlibat dalam perkara, maka pelaku harus melaksanakan ketetapan sebagai bentuk tanggung jawab yang harus dilaksanakan oleh pelaku. Bentuk tanggung jawab atau ganti rugi kepada pihak korban atas apa yang sudak dilakukan oleh pelaku. Hal tersebut sesuai dengan salah satu syarat formil berlakunya restorative justice sesuai dengan SE Kapolri No.8/2018, bahwa pelaku tidak keberatan atas tanggungjawab, ganti rugi, atau dilakukan secara sukarela (Wadjo \& Saimima, 2020).

Salah satu bentuk hukuman yang terdapat pada hukum adat di masyarakat Puncak Jaya adalah pembayaran denda adat. Denda adat dianggap sebagai ganti rugi dari kerusakan yang disebabkan oleh perbuatan tindak pidana yang dilakukan oleh pelaku. Maka dari itu, setiap denda adat yang sudah disepakati oleh kedua belah pihak harus dibayarkan. Proses pembayaran hukum adat dilaksanakan di kantor polisi dan disaksikan oleh penyidik dan pihak-pihak lainnya.

\section{Kesimpulan}

Restorative justice adalah upaya penyelesaian kasus pidana dengan menekankan akan pentingnya mempertahankan keadilan dan menstabilkan keseimbangan. Restorative justice memberikan kewajiban terhadap pelaku kejahatan dengan kesadarannya untuk mengakui kesalahannya dan melakukan permintaan maaf dan pengembalian kerugian serta kerusakan yang dialami oleh korban. Sehingga hal tersebut diharapkan dapat memenuhi rasa keadilan bagi korban.

Penerapan restorative justice terjadi atas kesepakatan pihak-pihak yang terlibat dalam kasus tindak pidana, tanpa adanya intervensi polisi di dalamnya. Penerapan pendekatan restorative justice dalam menyelesaikan kasus tindak pidana di wilayah hukum Polres Puncak Jaya dikatakan sangat efektif, dikarenakan lebih mampu untuk mengakomodir keinginan semua pihak yang terlibat dalam kasus tindak pidana. Sehingga hal tersebut menghindari munulnya konflik-konflik yang bisa saja muncul ketika satu pihak merasa keinginan/ kepentingannya tidak diakomodir.

Walau tidak berhak untuk melakukan intervensi atas penerapan pendekatan restorative justice, namun pihak reskrip Puncak Jaya sebagai penyidik berhak untuk menentukan apakah suatu kasus bisa diselesaikan dengan pendekatan restorative justice atau tidak. Hal tersebut dikarenakan wewenang dari penyidik serta syarat formil dan syarat materil yang harus dilengkapi ketika menerapkan pendekatan restorative justice. 


\section{BIBLIOGRAFI}

Apriyanto, Edwin. (2016). Penerapan Restorative Justice Sebagai Bentuk Diskresi Kepolisian Dalam Penyelesaian Perkara Tindak Pidana Penipuan di Polrestabes Semarang. Jurnal Spektrum Hukum, 13(1), 55-72.Google Scholar

Ariani, Nevey Varida. (2012). Alternatif penyelesaian sengketa bisnis di luar pengadilan. Jurnal Rechts Vinding: Media Pembinaan Hukum Nasional, 1(2), 277-294. Google Scholar

Bintang, Dedy Syahputra. (2021). Efektivitas Penerapan Restorative Justice dalam Menyelesaikan Kasus Tindak Pidana di Wilayah Hukum Polres Puncak Jaya. Universitas Tarumanagara. Google Scholar

Indonesia. (2012). Undang-Undang Republik Indonesia Nomor 11 Tahun 2012 tentang Sistem Peradilan Pidana Anak. Direktorat Jenderal Hak Asasi Manusia, Kementerian Hukum dan HAM, Republik Google Scholar

Jaelani, Andriansyah. (2020). Sanksi tindak pidana pencurian disertai kekerasan yang menyebabkan kematian perspektif hukum pidana islam. UIN Sunan Gunung Djati Bandung. Google Scholar

Maharani, Aprillia, Yuniningsih, Tri, \& Djumiarti, Titik. (2016). Efektivitas Dinas Sosial Pemuda dan Olahraga dalam Penanganan Anak Jalanan di Kota Semarang. Journal of Public Policy and Management Review, 5(3), 476-488. Google Scholar

Pandelaki, Glenn Richard. (2018). Peran Polisi Dalam Pengendalian Massa Berdasarkan Undang-Undang Nomor 2 Tahun 2002 Tentang Kepolisian Negara Republik Indonesia. Lex Et Societatis, 6(5). Google Scholar

Pohan, Hotman T. (2019). Analisis pengaruh kepemilikan institusi, rasio tobin q, akrual pilihan, tarif efektif pajak, dan biaya pajak ditunda terhadap penghindaran pajak pada perusahaan publik. Jurnal Informasi, Perpajakan, Akuntansi, Dan Keuangan Publik, 4(2), 113-135. Google Scholar

Purba, Irwansyah. (2016). Penerapan Hukum Pidana Militer Terhadap Anggota Militer Yang Melakukan Tindak Pidana Pembunuhan (Studi Putusan No. 295k/Mil/2014). Google Scholar

Rahman, Syaiful. (2017). Ganti Rugi Akibat Wanprestasi Dalam Transaksi Bisnis Berbasis Syariah Di Indonesia. Universitas Pembangunan Nasional Veteran Jakarta. Google Scholar

Tarigan, Irwan Jasa. (2017). Peran Badan Narkotika Nasional dengan Organisasi Sosial Kemasyarakatan dalam Penanganan Pelaku Penyalahgunaan Narkotika. Deepublish. Google Scholar

Umam, Islahul. (2016). Pemulihan Kondisi Sosial Masyarakat yang Rusak Akibat 
Efektivitas Penerapan Restorative Justice dalam Menyelesaikan Kasus Tindak Pidana

Tindak Pidana (Studi Kasus Aparat Gampong peulanggahan Kota Banda Aceh. UIN Ar-Raniry Banda Aceh. Google Scholar

Wadjo, Hadibah Zachra, \& Saimima, Judy Marria. (2020). Perlindungan Hukum Terhadap Korban Kekerasan Seksual Dalam Rangka Mewujudkan Keadilan Restoratif. JURNAL BELO, 6(1), 48-59. Google Scholar

Wahyudi, Dheny. (2015). Perlindungan Terhadap Anak yang Berhadapan dengan Hukum Melalui Pendekatan Restorative Justice. Jurnal Ilmu Hukum Jambi, 6(1), 43318. Google Scholar

\section{Copyright holder :}

Dedy Syahputra Bintang (2021)

First publication right :

Jurnal Syntax Idea

This article is licensed under:

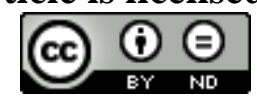

